\title{
Cosmopolitan recognition: three vignettes
}

This paper examines recognition in the cosmopolitan sphere of recognition - a sphere of ethical life and social freedom formed in the processes of recognition between individuals and groups across, over, and beyond, the state. The paper contends that Honneth's recognition theory can overcome many of the limitations inherent to established cosmopolitan paradigms, and, through normative reconstruction, provide a unique methodological framework from which existing cosmopolitan social relations can be examined. The paper argues that only a form of mutual recognition that satisfies both local and cosmopolitan ties of political community could adequately secure the intersubjective conditions necessitated in the Hegelian, ontological notion of freedom (freedom as 'being at home with oneself in one's other'). This contention is pursued through three interrelated arguments: (i) an engagement with Honneth's an emergent cosmopolitan public sphere.

Keywords: recognition theory; cosmopolitanism; Axel Honneth; critical

Many remain skeptical of cosmopolitanism both as a theoretical construct and as a political project. It is widely seen either as Western and modernist; a fetish of the American Academy; a programme labouring under an unabashed liberal ideology that barely masks a universalist quest for domination; or something purely idealistic against a global political landscape that remains firmly particularistic and statist. ${ }^{1}$ It is not the 30 purpose of this paper to engage this array of criticisms but to outline an 31 alternative, relational approach to cosmopolitanism through recognition.

${ }^{1}$ For a critical survey of these readings of cosmopolitanism see Ingram (2013, Chs 1-4), Harris (2003), Brennan (1997, 317ff). 
Recognition theory is premised on an intersubjective notion of freedom, derived from Hegelian philosophy, and expanded in the social theory of Honneth and his method of normative reconstruction. Its defense of a lived social freedom for all members through the mutual recognition of the needs, respect, and esteem, of individuals and groups, establishes a grounding of cosmopolitan politics within a positive account of diversity and difference in social relations - thereby distinguishing itself from those cosmopolitan approaches that operate under a closed monistic horizon or fixed institutional model. By using Honneth's recognition theoretic, the paper offers to reconstruct cosmopolitanism by locating it within some already existing relational practices and institutions of personal, private, and public, spheres of social life and to develop a cosmopolitan approach within this relational register.

The normative, political, and theoretical, implications of what I term in this paper cosmopolitan social-relations are significant and yet under-theorized in the literature. These relations refer to those between individuals and groups across, over, and beyond the state. Such relations are not bound solely by the juridical relations between self and other within the state or localized forms of ethical life (though they may originate and form a part of such spheres) and are global in scope or operation. Adapting Honneth's theory of recognition and method of normative reconstruction offers an analytical and methodological framework that can investigate these social relations and thereby move past two of the key limitations identified in contemporary cosmopolitan thought: the myopia of statism that continues to prevent the examination of social relations beyond the formalized relations within this geographical, spatial, and temporal construct, and, beyond the assumptions of nominal individualism that underlies cosmopolitan conceptions of civil society that reduces this sphere solely to a realm of strategic interaction. In distinction, through recognition theory, cosmopolitanism can be extended to the standpoint of human society or social humanity (to borrow from the Thesis on Feuerbach) in which intersubjectivity replaces these one-sided statist or nominalist ontologies. This leads into the political claim of the paper, that cosmopolitanism in IR must be rethought in 'relational' terms rather than in state-centred models (whether of a Kantian/federative or Wendtian/world-state typology), or the proceduralism of global institutional reforms (that would be disconnected to the people who would live in it), or through cultural developments refracted through a monist lense that would be oppressive in its particularity. Such models do not countenance the possibility of constructing cosmopolitanism through multiple traditions and forms of socio-cultural life, nor do they take seriously the question of grounding cosmopolitanism within real social-relations, without which cosmopolitan formalism, proceduralism, or moralism, would remain extraneous impositions rather than lived freedom. The benefit of recognition 
theory for cosmopolitanism stems from its unique capacity to meaningfully engage with socio-spatial relations at both local and global levels through which people construct their identity and on which they are reliant for the articulation, recognition, and actualization, of their freedom. The stakes cannot be higher in this debate. For without providing a frame that is grounded in real conditions that allows for a radical diversity in socially lived freedom and that permits open-ended processes for the continual expansion of freedom, cosmopolitanism will remain a dead or oppressive tradition. At the same time, if we abandon cosmopolitanism which, at its most basic conception holds to the promise of ethical human community that actively promotes the freedom of all, then we lose any grasp on the political question of our species: how can we live together and achieve the 'good life' for all?

To establish a groundwork of cosmopolitan recognition, the article proceeds in three sections. The first engages with Honneth's idea of the struggle for recognition for achieving the social conditions necessary for leading a 'good' or 'successful' life, a claim that is foundational for why we should be politically interested in mutual recognition in world politics at all. The second section outlines Honneth's method of normative reconstruction as a means to identify and explore the unique form of social freedom in the cosmopolitan sphere. The final section then deploys this method to examine three processes of recognition in cosmopolitan social relations located in forms of personal relations, in the extension of rights, and forms of solidarity in the global public sphere. The conclusion speculates on the ideal political and legal institutionalization of cosmopolitan recognition.

\section{Honneth's recognition framework: intersubjectively shared social freedom}

Honneth's recognition theory has yet to exert the influence on International Relations (IR) theory than it has in sociology and political science. While there is an emerging literature on recognition processes between states (see Lindemann and Ringmar 2012; Duncombe 2015), alongside some broader explorations of Hegelian themes of recognition in world politics (Haacke 2005; Heins 2005; Brincat 2015; Daase et al. 2015) - not to mention the significant advances in constructivism that developed through Wendt's productive use of recognition $(1999,282 \mathrm{ff})$ - there has been little engagement with the recognitive relations between individuals and groups that take place across, over, and beyond, states. An exception has been the Burns and Thompson's (2013) excellent volume that engages some of the themes regarding Hegel, Honneth, and global justice but even this does not explore the implications of recognition for cosmopolitan thought. These processes of recognition in cosmopolitan social-relations constitute 
an entirely unique dimension beyond the local forms of ethical life captured in Honneth's triad of 'love, rights and solidarity', all of which take place within the state (see Honneth 1995, Ch. 5). Analysis of these cosmopolitan forms of recognition are also absent in other models of recognition (i.e. Taylor 1992), and even in critics of recognition such as Markell (2003). Despite this lack of engagement, it can be readily assumed that in the conditions of late capitalism this sphere of global interaction bares tremendous impact on individual and group identity. For if recognition were to be cut-off at the local sphere of sittlichkeit, identity would be fettered in a truly oppressive form of isolation: one would be recognized locally but not in the world. Such recognition is partial, incomplete, onesided - it requires what Honneth should call a more comprehensive actualization (Honneth 2014a, 8-10). For recognition takes place at any point of interaction: it does not stop at the fence-line of one's village nor the border of one's state but can, and does, take place across, over, and beyond them - as has been done throughout the history of human relations, not only between individuals and groups but all the way up to civilizational encounters (see Cox 1995).

Despite these fairly obvious considerations, the vast majority of engagements with recognition (including Honneth's) remain bounded by the state as if this represented the outer limit of human community and bounded all processes of recognition. This is partly explained by the fact that Honneth's account remains located almost solely with Western European historical experiences and the institution of the nation-state, specifically its modern liberal democratic variant. This obvious Eurocentrism and Westernism has been a constant hindrance to the emancipatory project of the Frankfurt School (see Hobson 2007; Brincat 2012), for it has meant a myopic gaze on only one source of social structures supportive of emancipation. The argument of this paper offers a corrective by claiming that there are far wider forms of social freedom, nascent though they may be, in the cosmopolitan sphere. To borrow from Honneth's own reasoning, the normative claims within this sphere have 'not yet been redeemed in the historical process' and yet are 'filled with social demands for the realization of institutional promises of freedom' (emphasis added, Honneth 2014a, viii). That is, although transnational civil society and the global public sphere exist only in rudimentary forms, their actuality nevertheless presupposes a normative sphere of human relations that possesses their own practices of recognition, and, their own unique social demands for the realization of institutional promises of freedom. Of course, in comparison to the state, these may seem relatively underdeveloped in terms of institutionalization. Yet, such cosmopolitan social relations will become only more and more essential to individual autonomy given the expanded circles of interaction 
partners that is characteristic of late, 'globalized' modernity. If we take Q3 'relations of recognition as being constitutive for all of social reality' it follows that 'we must recognize that any explanation of social processes necessarily invokes prevailing norms and principles' within the totality of social reality (emphasis added, 2012, ix). Cosmopolitan ethical life is therefore necessarily implied in Honneth's theory of recognition. Such relations in the world already possess (limited) institutionalization through international law, normative political principles, and basic ethical practices - all of which, prima facie, affirm the existence of recognitive processes beyond the state, however, weak they may appear in comparison with local forms. For these reasons, to extend recognition theory to transnational or extrastatal relations of individuals and groups seems to be a logical development of the theory itself. The task then becomes one of locating and exploring the 'norms and principles' that pervade the cosmopolitan sphere, a question taken up in the final section of this paper.

But why should we be interested in recognition at all in IR? The key importance lies in its relational ontology and the different foundation this can bring to understanding cosmopolitan community. Honneth's recognition theory retains the 'ethical core' of CT regarding the idea of a socially effective rationality that could overcome social suffering and the violation of the conditions for a 'good' or 'successful' life for all. It believes the 'pathology of reason' - the distorted social developments endemic to late, global capitalism and liberal modernity - can be remedied practically. In this approach, a negative state of society is determined to the degree by which not all members are provided the opportunity (and conditions) for successful self-actualization. Honneth has deployed various ways to express the ethical content of such practices: as something necessary for individuals to meaningfully direct their lives, or, as the requirement for self-actualization under conditions common to all $(2009,22-23)$. Both of these ideas harken back to Hegel's famous entreatment that we cannot be free alone: that freedom is 'to be with oneself in the other ...' (1970, $\mathbb{2} 24 \mathrm{~A})$. Here, freedom is a social achievement. Conversely, any 'deviation' from this ideal of a socially situated freedom of 'leading a successful undistorted life together' is believed 'must lead to a social pathology insofar as subjects are recognisably suffering from a loss of universal, communal ends'. This loss is experienced as suffering because it is only together, through refined intersubjective relations, that the conditions for our own self-actualization - with and through all others - can be secured. The exposition of those circumstances that block or inhibit this process should then have the 'rational force' to convince subjects to overturn such distortive practices to 'create' the necessary 'social practice[s] of cooperation'. For this fundamental reason, Honneth's has sought to revivify the struggle of recognition through which this ideal of mutuality can be better 
established - either through the expansion or extension of recognition 198 processes - through which all social members can relate their freedoms to one 199 another 'cooperatively' (2009, 24-26, 29). Emancipation, then, hinges on 200 securing the social conditions necessary for attaining this positive self-relation 201 with all others through processes of mutual recognition.

The question of how to universalize freedom has been perennial one 203 for cosmopolitanism - the fears and indictments of the imperialistic and 204 exclusionary tendencies of cosmopolitanism all stem from this central 205 problem. It is through this question that recognition can enter such debates in 206 IR by providing a positive account of diversity in claims of individual and 207 group freedom. Honneth carefully positions his recognition theory in two 208 ways. First, he anchors his approach in Hegel's account of the struggle for 209 ideal of 'intersubjective understanding' that makes possible the specification 210 of 'politically significant' emancipatory practices through domination-free 211 networks of interactive relations (see Honneth 1991, Chs 7 and 9; 212 Honneth 1995, 97, 106, 115, 117-18, 120, Chs 1 and 5). Second, Honneth 213 situates The Struggle for Recognition in opposition to the philosophical 214 anthropology of Hobbes and Machiavelli whose atomistic ontologies allege 215 egocentricism and competitiveness as intrinsic to humankind. Contesting 216 such ontologies that deem social conflict to be motivated solely by 217 self-preservation, Honneth suggests that social struggles are motivated by 218 moral impulses, specifically, violations of social relations of recognition. 219 The violation of moral expectations for recognition - and the perception of 220 these failures as injustices, disrespect, or denigration ${ }^{2}$ - provide Honneth 221 with a model of social struggle towards the establishment of ideal processes of mutual recognition. At the nominal level, it is the individual or group's moral sense of wrongful violation of a moral expectation for recognition that motivates struggles. At the ontological level - and why recognition is deemed to have a universally emancipatory character - is because all humans require recognition as essential for their own stable construction of personal identity and self-actualization, a basic pre-requisite to their freedom. Taylor, in similar manner, calls recognition a 'vital human need' $(1992,26)$. Struggles for recognition, then, are a 'central medium' in humankind's process of ethical development towards a 'state of communicatively lived freedom' (Honneth 1995, 5-10, 13).

Whilst reliant on some of the most highly contested fields in social theory (see esp. Honneth 1995, Chs 3 and 4; Honneth 2012a, 228; Honneth 2014a, 35),

${ }^{2}$ Consistent with the broader German translations, 'to recognize' is to ascribe an individual or group some positive status and, conversely, to 'disrespect' or 'denigrate' includes a broad range of failures to recognize including, but not limited to, humiliation, degradation, insult, disenfranchisement, and physical abuse (see Anderson 1995). 
Honneth justifies the emancipatory potential underlying recognition matter-of-factly: 'the reason we should be interested in establishing a just social order is that it is only under these conditions that subjects can attain the most undamaged possible self-relation, and thus individual autonomy' (2003, 259). Moreover, to deflect charges of relativism, Honneth affirms that whilst recognition is universal in its necessity for stable identity formation, the actual practices of recognition are immensely diverse and can be satisfied in any number of ways. For Honneth, there are a 'multiplicity of forms of recognition' varying with the layer of personality to be affirmed. While the need of love, rights, and solidarity forms an 'anthropological constant' the social expectations of recognition can, and will, vary across time and place (see Honneth 2007, 351; Honneth 2008, 130). In other words, recognition is a genus comprising various forms rather than one set social practice. This myriad forms that recognition may take are, however, all 'practical attitudes whose primary intention consists in a particular act of affirming another person or group'. Due to this affirmative character, Honneth regards them as 'unambiguously positive' because 'they permit the addressee to identify with his or her own qualities and thus to achieve a greater degree of autonomy' (2012a, 81). Consequently, self-autonomy is seen as dependent on the social establishment of relations of mutual recognition within three primary relations: love and friendship (related to needs and self-confidence); legally institutionalized rights (related to dignity and respect), and; ethical life (through the esteem of one's unique attributes in society). By experiencing these forms of recognition the individual comes to experience themselves - and all others - as possessing a certain status: as the bearer of needs, as a bearer of responsibility (and agency), and as a bearer of something unique, something of social value. The actualization of self-autonomy is therefore predicated on the intersubjective achievement of self-confidence, self-respect, and self-esteem, achieved through the 'recognition by others whom one also recognizes', that is, mutually (Anderson 1995, xi). These ideal social conditions are typically expressed as the triad of 'love, rights and solidarity' that, taken together, provide the social context necessary for the 'practical relation-to-self' to emerge (Honneth 1997, 234, 237). A disturbance or distortion in this process is marked by domination, not just in communicative relations, but in patterns of recognition also. The ideal of mutual recognition thereby offers a standard of critique of existing social conditions that do not meet the requirements for stable identity formation and self-autonomy. That is, all societies - including international society - can be judged by the degree to which all members are provided the opportunity (and conditions) for successful self-actualization. Moreover, the ideal of mutual recognition provides a reason for social struggles against 
existing distorted or limited processes of recognition and thereby a vision - 277 however, contingent - of what, and how, social institutions can and should 278 be augmented, changed, or modified accordingly.

Since its publication in 1995, the central tenants of Honneth's account 280 of struggles for recognition have been well-traversed. But it is only in 281 combination with Honneth's more recent work that we can begin to more 282 fully explicate the stages of identification/autonomy that subjects must pass 283 through with the social conditions necessary for their actualization. For 284 Honneth, to constitute mutual recognition such social practices must ascribe 285 a special type of normative status on individuals and 'co-produce' a specific 286 form of individual relation-to-self $(2014 \mathrm{a}, 105)$. Society is described as a 287 'layered arrangement of recognitional relationships' either more, or less, 288 corresponding to the ideal of mutuality (see Honneth 2012a, 24-26; 289 Honneth 2014a, 46). The content of these 'layered arrangements' are 290 essential for the simple reason that 'freedom cannot be realized without 291 taking into account the institutional forms that enable its realization' and 292 hence the normative legitimacy of any society is dependent on whether and 293 how it ensures the basic preconditions of individual self-determination 294 (Honneth 2014a, 41, 16). For Honneth, it is only within institutions marked 295 by 'complementary role obligations' that ensure the recognition of others 296 activities as conditions for one's own aims. Here, personal relations, the 297 market, and the public sphere, form the 'relational institutions' (Parsons) or 298 'ethical spheres' (Hegel) of potential social freedom. But, the reality or 299 actualization of freedom within these spheres can 'only be given if we 300 encounter each other in mutual recognition and can understand our own 301 actions as a condition for the fulfilment of others' aims'. For it is only under 302 such conditions that 'we can experience the realization of our own intentions 303 as something that is entirely unforced and thus "free" because it is desired or 304 strived for by others within social reality' (Honneth 2014a, 124). Mutual 305 recognition, in this way, can be seen as the: 306

reciprocal experience of seeing ourselves confirmed in the desires and aims 307 of the other, because the other's existence represents a condition for 308 fulfilling our own desires and aims. Once both subjects recognize the need 309 to supplement their respective aims, thus seeing their own aims in the other, 310 merely reflexive freedom becomes intersubjective freedom ... Subjects must 311 have learned both to articulate their own aims to the other and to 312 understand the other's articulations in order to recognise each other in their 313 dependency on each other (Honneth 2014a: 44, 45).

So, by examining the personal, private, and pubic spheres for those 315 institutions that ensure 'reciprocal comprehensibility' between interaction 316 partners, society can be judged as 'bundles' of behavioural norms, 
expectations, and practices, that socially integrate individual aims. Through these practices established in social institutions (albeit practices that are never fully secure but which must be performed), subjects have an 'upbringing' (Bildung) within reciprocity in which their goals/aims can only be satisfied through complementary acts of others and are appreciated as such. It is a 'closed feedback loop' that constantly invites the realization of complementary and cooperative aims (Honneth 2014a, 48, 49), coupled with the potential for struggles for expansion/extension where these practices or institutions are unsatisfactory or incomplete. Because such institutional complexes provide subjects with social conditions that allow the reciprocal realization of freedom, they thereby constitute 'congealed' forms of mutual recognition, 'lasting embodiments of intersubjective freedom' (Honneth 2014a, 53).

The implications of these core tenants of Honneth's recognition theory for my argument are twofold: that the claim to cosmopolitan recognition stems from the very fact of being human and the need for stable identity formation that corresponds to this cosmopolitan sphere, and, that the existence of such cosmopolitan relations amongst peoples of the world can be reasonably demonstrated. These are not mutually exclusionary tasks: what is required is first to first show that there are presently such recognitive interactions in world politics, and, then examine the relative strength of these patterns for identity formation, judged by their level of reciprocity or institutionalization. The theory does not require that cosmopolitan recognition patterns must manifest in strong interactions nor have reached the ideal of mutuality. For even if they are weak, distorted, or poorly institutionalized, not only demonstrates their existence (however, insufficiently articulated within international society) but, on the premises of the theory itself, would suggest sites of possible future struggles for recognition. As the final section demonstrates, there are identifiable forms of such cosmopolitan recognition processes in world politics, regardless of, however, relatively under-developed they are practiced in comparison with the institutionalization of the state or market.

In many respects, my argument follows Deranty and Renault's $(2007,92)$ call for the politicization of recognition - or the realization, through politics, of the normative demand for autonomous identity - made within the context of IR. However, there have also been various criticisms of Honneth's theory on this point. Fraser, perhaps most famously, has posited that participation is required for just social relations, something that, for her, can only be attained through status, resources, and voice. Here, recognition can only play a limited social role. Honneth has responded, however, by claiming recognition is essential to form integrated social identities and self-actualization, and therefore constitutes something necessarily prior to questions of 
Q4 justice and distribution (Fraser and Honneth 2003, Ch. 3). Rancière, in a more recent dialogue with Honneth, has challenged that recognition theory relies on an overly substantial conception of identity. Honneth has countered that recognition provides the possibility for the increasing possibilities for social freedom in which struggles for recognition are ongoing sources for socio-political transformation (Honneth and Rancière 2016). It is not the purpose of this paper to engage all such criticisms of Honneth's framework, or recognition generally, something that would require a separate project. But what is of importance is how Honneth's replies to these various criticisms indicate that if recognition promotes integrated social identities and self-actualization, and, increases possibilities for social freedom, then there is a demonstrable need to explore the implications of recognition in the context of world politics and the possibilities of the social relations in the cosmopolitan sphere - something Honneth (2012b) has only begun to examine.

\section{Normative reconstruction: understanding cosmopolitan forms of recognition}

But how can we examine this sphere of cosmopolitan recognition, given that one of the typical detractors of the cosmopolitan tradition is its alleged lack of political actuality - the objection that its 'vision' is simply not the case in today's world? One of the fundamental contributions of Honneth's later work is the method of 'normative reconstruction' that he develops to answer just such a question. Honneth $(2012 \mathrm{a}, 60)$ deduces that as we cannot make appeals to activities external to society without falling to utopianism or moralism, it follows that we must instead draw upon the norms that already constitute rational claims in society. This is consistent with the methods of immanent critique of the Frankfurt School. Rather than drafting some ideal conception of the good, normative reconstruction traces the relations, values, and ideas, that are already embedded in society (Honneth 2014a, 59-63). Using this approach, Honneth charts the Das Recht der Freiheit (Right to Freedom) as it has developed historically in social relations and been socially institutionalized - a deliberate extension of Hegel's Philosophy of Right that reconstructed 'rational institutions' defined as those social institutions that guarantee freedom (2014a, 1).

Normative reconstruction does not merely reinforce what is already practices dialectically by anticipating 'other paths of development' that 
comprehensive and suitable fashion'. Expressed alternatively, it seeks out 'the neglected potential of already existing institutions'. The method becomes a procedure for criticizing social reality by exposing the gap between values and their actualization (Honneth 2014a, 8-10). So the purpose is not just reconstruction but the critique of the structural normativity of social institutions in order to grasp the various social forms in which freedom manifests itself, to thereby unveil the social defects and pathologies, the missed opportunities and possibilities, of human freedom within social reality. Normative reconstruction is prefigurative but socially grounded, seeking to build upon (or make consistent) the normative principles of society and their normative practice. In short, it aims to hold society to account for its promises of freedom. Whilst a seemingly boundless task given the number and complexity of social norms, the method focusses only on those institutions that are 'indispensable for social reproduction' as determined by the respective function they fulfil for the actualization of social freedom (Honneth 2014a, 6). This allows the method to systematically examine the forces of social integration that guarantee social freedom, defined as those institutions marked by 'complementary role obligations' that ensure the recognition of others' activities as conditions for one's own aims through 'unforced reciprocity' (Honneth 2014a, 55, 56).

The method pursues the systematic examination of what forces of social integration exist within each constitutive spheres of human freedom at a given time, that is, in primary relations, civil society, and public-life. Analysis traces how these spheres have historically developed to institutionally embody a 'particular aspect' of individual freedom, which can then be judged by the 'degree to which the understanding of freedom institutionalized within them has already been socially attained' (Honneth 2014a, viii). It is here that Honneth admits a crucial part of this method through which cosmopolitan social relations can be reconstructed and their function of social freedom understood. He does this in two ways. First, Honneth states that '[n]ormative reconstruction must be directed towards the entire spectrum of reciprocal social relationships if we are to truly disclose all the conditions under which subjects achieve autonomy' (emphasis added, 2012a, 49). Second, Honneth focusses only on those social relations that guarantee social freedom, those that ensure the recognition of others activities as conditions for one's own aims (2014a, 55, 56). The former implies that we must look to all such social relations through which subjects achieve social autonomy, including those in the cosmopolitan sphere, however, weakly these may be institutionalized. The latter holds that we should then focus on those types of relations that possess reciprocal role obligations purposed towards social activities that ensure the recognition between interactive partners. Honneth focusses his attention on those institutions considered reproductive for social freedom 
within the state (primary, social, and public spheres) and yet, on this basis, we would be equally justified in pursuing a fourth dimension of cosmopolitan recognition in the world, charted through the sequence of developments in the spheres of freedom that must be achieved to form 'stable institutions' or 'habitual attitudes' towards mutual recognition in world politics. Put simply, if normative progress is traceable through greater degrees of individualization and social inclusion in practices of recognition, as Honneth claims, then the cosmopolitan sphere forms a crucial dimension for the necessary expansion and extension of recognition in the world (2014b, 563).

Honneth has recently grappled with some of the questions arising from the turn to recognition in world politics. Focussing on recognition between states, he has suggested the possibility of reducing conflicts and improving peaceful cooperation through 'sustained efforts at conveying respect and esteem for the collective identities of other countries' (Honneth 1997, 33-35). Yet, he has deliberately eschewed engaging with questions of cosmopolitan socialrelations and their connection to the triad of 'love, rights and solidarity'. In fact, Honneth openly doubts whether differentiating between various modes of recognition at the highly aggregated level of entire populations, such as states, is appropriate. For him, judging whether such populations are struggling for 'signs of goodwill, legal equality, or esteem in the eyes of the other side' is almost impossible given that populations are far too heterogenous and individual members' motives too diffuse to be sufficiently integrated (Honneth 2012b, 33). Yet, as Ringmar $(2012,7)$ has countered, while this may be true as a matter of empirical investigation, it has no bearing on analytical distinction. The heterogeneity of state populations may preclude any simple 'up-scaling' of individual psychological and group sociological processes of recognition to state populations, but it is not prohibitive of studies, like my own, that seek to analyse cosmopolitan social-relations between individuals, groups, and peoples across states because such differentiation remains possible even at this scale-albeit with considerable research challenges. In fact, by examining the level of cosmopolitan social-relations through the recognition framework and the method of normative reconstruction, such practices cease to remain abstract and nebulous and can be differentiated through any number of empirical processes/phenomena of interaction/s observable in the cosmopolitan sphere. In a recent reply to sympathetic critiques of his account of recognition in IR, Honneth has noted that some aspects recognition in this dimension have not yet received sufficient attention (i.e. colonialism) and expressed support for the importance of transnational solidarities as a crucial element of recognition in IR (2014b, 564, 65). Moreover, as Honneth has called the domain of recognition in IR as a 'moral substrate' indicates that it does form part of the totality of such recognition processes in social life, something that hints at a 'supra' 
cosmopolitan dimension that corresponds to the individual situatedness in the world $(2012 \mathrm{~b}, 25)$. Under the pressures of increased global interactions stable practices of recognition are essential not only to ensure basic (non-violent) encounters with others but also to ensure the far more arduous task of ensuring sufficient processes for the fulfilment of autonomy than what is possible at the local sphere alone. As we shall see in the next section, elements of recognition in this cosmopolitan sphere are already present, however, much they lack sufficient institutionalization and comprehensiveness.

\section{Recognition and cosmopolitan social-relations: three vignettes}

We have seen that the normative ideal of recognition promotes integrated social identities and self-actualization, and, increases possibilities for social freedom. Honneth has been concerned with uncovering these processes in personal, private, and public spheres, within the state. But do they also exist in the cosmopolitan sphere? The task of this final section is to identify the existence of such processes within cosmopolitan social relations and assess their relative strength (i.e. demonstrating the level of freedom socially institutionalized and the level of reciprocity within such practices between interaction partners). Borrowing from the framework of The Struggle for Recognition, this section examines some examples of cosmopolitan practices of recognition related to neediness and self-confidence; respect and dignity; and forms of self-esteem. At the same time, following the method of normative reconstruction from Honneth's Freedom's Right, it discusses the institutionalization of these practices of recognition in the cosmopolitan sphere that would qualify them as 'mutually complementary role obligations' that ensure the recognition of others activities as conditions for one's own aims (Honneth $2014 \mathrm{a}, 127)$, or expressed in another way, the degree or comprehensiveness to which they permit the addressee to identify with his/her own qualities and thus achieve a greater degree of autonomy (Honneth 2014a, 81). I outline three dimensions to this 'moral substrate' of cosmopolitan recognition that map neatly onto Honneth's framework and which indicate the normative horizon that 'patterns' recognition in world politics. The three examples include (i) the enhancement of personal freedom through expanded forms of interaction in personal relations of love and care; (ii) the legal recognition of moral personhood under the universal human rights (HR) regime in transnational civil society, and; (iii) international social movements and forms of deliberative institutions in the global public sphere. It should be noted that while presented as separate, each sphere overlaps, so that the struggles and institutions, and, the misdevelopments and pathologies in each sphere, affect the others. Moreover, for reasons of length, only one example is given in each 
vignette and are intended to spur further research, rather than to be taken as covering-the-field. That is, the list is indicative, with the vignettes chosen as illustrations of cosmopolitan recognition rather than being exhaustive of all such practices.

In personal relations - such as friendship, family, and physical relations realization on the basis of need and affection. Such relations are foundational as they embody a form of relation in which the 'inner nature' of the individual 'is set free by mutual confirmation'; they involve forms of interaction 'whose reciprocal fulfillment allows us to experience the intersubjective realization of our respective individuality'. It is this experience of 'reciprocal fulfillment' that allows the basic intersubjective realization of one's respective individuality in, and through, the other (Honneth 2014a, 132-34). From his earliest writings in System of Ethical Life to the Philosophy of Right, Hegel consistently referred to love as an ideal external relation in which the individual attains self-awareness only by regarding 'the other as other' (Honneth 2014a, 43, 44, citing Hegel 1991, $\mathbb{~ 7 , ~ 4 2 ) . ~ S u c h ~ a f f i r m a t i o n ~}$ through affective relations are limited, however, for in comparison with legal rights that obligate all social members to treat others according to equal claims, love cannot be generalized beyond a small circle (Honneth 1995, 49, 107, 156-59). This lack of generalizability may make it appear that cosmopolitan social-relations can only be loosely tied to this primary circle of love, given that the innocuous and the seemingly non-political nature of interpersonal relations, whilst of considerable importance to the individuals involved, seem to bare little impact on world politics. Yet, love and friendship facilitate the development of fundamental relation-to-self (i.e. the expression of one's needs and desires without fear of abandonment) and are therefore a precondition for the development of all other forms of self-respect. As such, the sphere of love is of acute social significance for individuals to feel their natural neediness is institutionally protected in a specific form of mutual recognition forming elementary self-confidence (Honneth 2014a, 154). Its primary basis represents a 'kind of school' for the 'structural developments within the human psyche' necessary for modes of comportment in private and public life (Honneth 2012a, ix-x). As Honneth affirms, whilst personal relations may have considerably less 'institutional anchoring' than the private and public, changes in the institutionalization of personal relations 'are just as socially significant as those in economy or society' (2014a, 134).

Personal relations are reliant on intimacy, privacy, and reduction of constraints on the personal relations we may choose. That is, the experience of 
reciprocal recognition in individual freedom can only be achieved through the 'aid' or support of permissive social institutions that give space, legitimacy, and respect to such personal relations through which subjects can begin to relate to each other reciprocally and thus actualize certain aspects of their autonomy (Honneth 2014a, 45, 46). The question then centres on the presence of supportive infrastructure in the cosmopolitan sphere for friendship, intimate relationships, and families, without which the autonomous aims of subjects could not be fully secured or integrated. Developments around marriage is the obvious example and in the cosmopolitan sphere we find strong legal opportunities to secure such relations across state borders (Visas and migration), and we can trace similar historical development such as the declassing and deracializing of friendships and intimate relations across state borders. In part, the freeing of such relations corresponds to Kant's cosmopolitan right of hospitality (2005, Third Definitive Article, 105ff) that whilst ostensibly restricted to the right of movement/visitation and nonrefoulment, by invoking some sense of a responsibility of the community to which the 'other' has presented, performs the social function of creating space - and thus extending the possibility - for personal relations to emerge and flourish in the cosmopolitan sphere. Moreover, basic relations of love are essential for acknowledging the neediness of others in the international community and are therefore foundational to forms of solidarity for the suffering of others linked to humanitarian assistance, aid, and development. Indeed, if love is concerned with reflections of neediness between self and other, then empathy and emotional engagement cannot be excluded from cosmopolitan recognition process but are intimately bound to them. A lack of empathy, especially indifference to human suffering in cases of natural and humanitarian crises, will be felt as disrespect by those people affected - we can think here of the continued indignation of the Rwandan people against the Western passivity in 1994, or in contrast, the solidarity that emerged in response to the 'Boxing Day' Tsunami coloured by colonial representations and 'pity' (see Hutchinson 2014). Here, it is the relational aspect of empathy and emotional engagement in cosmopolitan forms of recognition that are revealed as essential to the development and performance of other forms of recognition, both rights and solidarity. Indeed, these more expansive forms of recognition are largely dependent on the prior establishment of conditions in which such personal feelings for the other can emerge.

Arguably one of the strongest examples of emergent practices of recognition supportive of personal relations in the cosmopolitan sphere is found in the struggles for liberation and rights of the LGBTQ community across the globe. In part, this overlaps with struggles for legal recognition of moral personhood under the universal HR regime (and would seem best accounted strictly under 'rights' discussed in the next section). Yet, such a move would 
lose sight of the real lived forms of social freedom through personal relations that such rights are intended to allow the space for. For the LGBTQ community can only experience such personal freedom and overcome non-discrimination if they can sustain the personal relationships they wish. ${ }^{3}$ Regardless of classification, even in those polities that have tolerant laws for LGBTQ relationships, individuals are disadvantaged by lack of legal opportunities related to economic partnerships (tax and economic security) and familial rights related to adoption, amongst other inequalities. The ongoing denial of marriage rights constitutes an injustice by denying the benefits of heterosexual family system (what Honneth calls the 'community for life' that helps support the formation of an individuals neediness) to such couples; and the repression of such relations of intimacy prevents the actualization of autonomy through bonds of 'mutual affection' (Honneth $2014 a, 171,167)$. The denial of such basic needs has clear infractions on individual autonomy the world over - personal freedom, quite simply, is repressed by others. It is not just that the LGBTQ community lacks access to the family system (nor should it be reduced to this formal claim alone that would be incomplete) but also that the social freedoms that emanate from this institution are constructed on normatively heterosexual terms that limit the expression of personal freedom in dominant social institutions. Some activists view the gay marriage movement as pursuing a distinct form of misrecognition, insofar as it seeks to assimilate 'queer' forms of sexuality to a heteronormative standard. Here, recognition is not genuinely mutual but bound to a dominant normativity. Access to marriage 'equality' is therefore only partial liberation, requiring a fuller expression that could ensure the freedom of personal relations beyond this dominant framework. Such claims for recognition can never be reduced to the dominant standard even though they may seek entry to it but, consistent with normative critique, the analyst must pursue ways in which these claims can be exceeded beyond their institutionalization. That is, further struggles of the LGBTQ for independent demands of their particularities beyond the 'majority culture' (Honneth 2014a, 289) can be expected. ${ }^{4}$

${ }^{3}$ A point of clarification is here required, as it may seem that this discussion should appear in the second vignette related to 'rights'. However, rights, amongst other things, are a space for which personal freedoms can operate. Such legal guarantees enable social freedom but which are largely dependent on what Honneth calls 'non-legal relations or feelings of commitment to pre-legal norms' - that is, they are reliant on the social interaction (relations) of 'non-legally cooperating subjects' (see Honneth 2014, 86). All sphere are inextricably linked. In this case, intimate relations cannot be divorced from respect of those relations, which in turn cannot be reduced to mere legal notion of respect of equality, but of the pre-legal recognition of the worth of the relation to be attained.

${ }^{4}$ Arguably, Honneth's (2014: 150) optimistic assertion that in the long term that justifying exclusion from equal marriage will 'dry up' leaving two options, to either abolish marriage 
Part of the articulation of these independent demands beyond majority culture is observable in how such struggles have taken on cosmopolitan character, seeking to extend personal freedom and expand the notion of 'right'. That is, the 'double movement of globalization' in terms of LGBTQ rights has expanded the claims to HR as a criterion of validity across all states and furthered such claims as related to identity. The Declaration of Montreal (2006) and Yogyakarta Principles (2007) are viewed as products of the successful intensification of struggles for LGBTQ sexual orientation and gender identity as an application of HR, thus signalling the overturning of previous conceptions of the 'human' in which such individuals were absent (see Butler 2004, 17-39). Moreover, transnational activism in this area constitutes a unique form of social struggle, one that has been having demonstrable impact across the globe. Here, new alliances and linkages within transnational networks are helping push forward the actualization of personal relations essential to identity and autonomy that in many respects cannot be satisfied comprehensively within many local contexts. Such struggles require the cultural translation of universal LGBTQ rights into the public discourse of domestic polities by presenting LGBTQ demands as universal demands (see Birdal 2015). Consider the European example in which gay rights are being claimed in two supranational institutions, the European Union (EU) and the Council of Europe. Whilst activities range from official lobbying (through advocacy associations, some of whom have official status in European structures, i.e. the ILGA) to civil disobedience, these struggles are primarily - though not exclusively framed as one of universal HR related to equality, respect, and freedom. While expressed in the legal nomenclature of right, they are nevertheless for the social actualization of personal freedom - 'personal relationships [that] represent social relations in which our inner nature is set free by mutual confirmation' (Honneth 2014a, 132). Cases seen at the European Court of Justice demonstrate the growing legalization of this struggle as a form of state, local, and regional regulation, whereas wider socio-cultural struggles (perhaps most visibly demonstrated in the protests against the Russian Winter Olympics and incarceration of Pussy Riot) are pushing towards processes of recognition in shared cultural practices that produce social legitimation, and can therefore be seen as preconditions for the formalization of legal protections. Stychin has found that framing this struggle in the discourse of universal HR has been successfully deployed in LGBTQ activist struggles outside of Europe in which international legal 
standards have helped overcome particularities at the local level. This has offered new recognitional practices and infrastructure by which such struggles can appeal to normative principles and practices outside mere local forms of ethical life and at the same time helping reclaim the LGBTQ history of such communities towards the extension of personal freedom (Stychin 2003-2004, 951).

Of course, within existing international institutions these claims are expressed within thematics already established (e.g. as sexual rights clustered in UN forums related to population, health, and violence) (see Wilson 2002, 253-65). The danger in the cosmopolitan sphere concerns whether the articulation of these rights merely reflects the limits of sexual diversity considered acceptable by international society or its dominant cultural pattern at a certain point in history. Recognition could then be grossly inadequate, limited to the categories dominant within the ethical life of international society. Similarly, the push for rights claims renders the struggle unevenly towards legalism, as opposed to the formation of wider solidarities, so that the goal becomes judicial arbitration rather than normative and communicative interaction (Honneth 2014a, 87, 90). The task then is to re-affirm the basis of such claims, not in its exterior form as a claim of right, but as a form of personal freedom in which the liberation of such personal relations is seen by the community as essential for such individuals to be fully self-actualizing (Croce 2015, 2). While the legal procurement of rights may open space (or protect space) for the articulation of personal freedoms they remain necessary yet altogether insufficient for autonomy.

Despite its limits and contradictions, the cosmopolitan dimensions of these struggles of the international LGBTQ community demonstrate a unique transnational solidarism - what has been described as a reconfiguration of 'the international' (Baker 2016) - that, once again, demonstrates the key linkages and dependencies between the spheres of recognition and forms of social freedom. The cosmopolitan dimension of these activities has assisted local groups by providing external normative/ moral but also practical/organizational resources where such recognitional processes at the local levels have been attacked, blocked, or absent. The successful attainment of rights in a number of states illustrates an effective, albeit partial, institutionalization of these demands. In this sense, the cosmopolitan sphere has proved an active site of recognition practices above, between, and beyond the state. The transnational nature of these actions indicates both an expansion of the circle of recognition for such personal freedom and an extension of the content of the nature of sexual, intimate, or 'personal' freedoms than contained in these local spheres alone. Nevertheless, in the conditions of late, global capitalism, the furtherance of 
'the radical egalitarianism of love' is hard-pressed. As Honneth $(1995,176) \quad 715$ posits, such personal relations must not only be pushed for, but defend 716 against, any number of forces emanating from civil and public spheres.

\section{Rights, self-respect, and private relations}

Rights play a significant role in the formation of the practical ego by giving the subject position and dignity as a member of a social community - and hence the wide ranging struggles for the types of autonomous actions that 'rights' enable (such as personal freedoms described in the previous vignette). Recognition of individual 'personhood' affirms the legal equality and moral self-direction of individuals and is therefore fundamental for the expression of needs in personal life, the pursuit of private freedom in civil society, and the articulation of communicative freedom in the public realm. Simultaneously, rights constitute a layer across the cosmopolitan sphere regarding the universal recognition of respect of these qualities in all human beings, presupposed in the concept of universal HR and coded in The Universal Declaration of Human Rights (UDHR) (1948) itself. This cosmopolitan extension and expansion of rights allows the individual to comprehend themselves as capable of participation in all social spheres because they confer the status of a morally responsible person with agency -a capacity reciprocally shared not just between those within formal (state) community (Honneth 1995, 40, 49, 79), but now across all of humankind. Yet, rights should not be elevated one-sidedly, for as stated previously, they only ensure space for the reflexive examination on personal decisions and do not, of themselves, realize such aims (Honneth 2014a, 27, 124). Rights must be articulated not only through legal adjudication but through social-relational and communicative aspects of freedom in community. Despite this limit, however, the scope and content of rights is not determined once and for all. Rather, for Honneth, there is an 'essential indeterminacy' to what constitutes a responsible moral agent and therefore a 'structural openness on the part of modern law to a gradual increases in inclusivity and precision' $(1995,110)$. This developmental potential captures the process by which all members of a community experience 'a gain in personal autonomy in virtue of having their rights expanded' and through which the community itself can be seen as 'enlarged' by increases in individual liberty (Honneth $1995,85,86)$. It is through this radical developmental potential that we can observe how cosmopolitan social-relations have contributed greatly to the creation of unique forms of rights by giving both legal and cultural affect to moral personhood under the universal HR regime.

For Honneth, the content of self-respect and the universal capacities considered to reside in each individual shifts over time (see esp. 1995, Ch. 6). 
This developmental potential implies at least three things, all of which indicate 755 the importance of the cosmopolitan dimension to the contemporary actuali- 756 zation of rights. First, there can be an expansion in the number of people who 757 are treated as bearers of such rights through the expansion of citizenship or 758 the coverage of existing legal rights. Second, there can be an increase in the 759 content of what it means to be a bearer of such rights. That is, there can be 760 development of what - at both material and ideational levels - is considered 761 as essential for self-respect and the legal/formal content to reflect such 762 understandings of moral agency. In this case, Marshall's (1950) account of the 763 addition of welfare rights to existing civil rights is routinely discussed as an 764 example of how the actual content of rights can develop over time. This is 765 indicative of how the content of cosmopolitan rights have developed via 766 similar processes (albeit partial and incomplete) from basic rights in UDHR, 767 to later include wider civil and social content in the related Covenants on 768 Economic, Social and Cultural Rights ${ }^{5}$ and Civil and Political Rights (1966), 769 and further diversifying into specific rights gains for particular groups 770 [i.e. rights of the child (1989), migrant workers (1990), and persons with 771 disabilities (2006), amongst others]. In this history, the formation of the 772 International Criminal Court $(1998)^{6}$ can be seen as the product of 773 the immanent institutionalization of global criminal law that builds on 774 Habermas' reflections on the universal HR regime as a positive and coercive 775 legal order upon which individuals can make actionable legal claims realized within the context of a cosmopolitan legal order (see Sorial 2008, 241-65). Third, as rights ensure the opportunity for individuals to exercise their universal capacities and thus actualize their social freedom within community, implies that rights need to be reflected widely throughout social relations in order to give affect to the ideal conditions for 'successful self-actualization'. That is, the full articulation of one's self-respect necessitates a borderless dimension to rights - an extension of cosmopolitan civil law - so that one's agency could be expressed throughout the world, the absence of which would constitute an unnecessary restriction of the recognized agential capacities of individuals. Framed accordingly, we can see how the universal recognition of the moral personhood of all human beings has solidified a moral vocabulary

\footnotetext{
5 This covenant, whilst routinely unmet, nevertheless points to the potential for more comprehensive actualization of HR as necessary to further personal freedom. It also highlights a key issue for rights to be articulated meaningfully in the market (see Honneth 2014, viii, 41) - a complex issue beyond the scope of this paper.

${ }^{6}$ The creation of the International Criminal Court did not, however, bring with it an expansion in the content of legal protections but merely affirmed customary international law. Its primary concern was to create an institutional framework for enforcement that could, however, provide the space for such developments in the future.
} 
and institutionalized processes in which claims for recognition in the cosmopolitan sphere can be practiced and made the site of ongoing social struggles for further development and expansion across both domestic and international spheres. That is, the reasonable expectation of one's recognition as a human being (with capacities shared with all others) has developed from a cosmopolitan principle to a number of formal cosmopolitan practices, through which we can anticipate 'other paths of development' that have not yet been exhausted within these established practices. This nestles with Honneth's expansive notion of autonomy as a 'positive-feedback loop', for the more capacities and preconditions we regard as a necessary aspect of individual agency, the more we have to consider the views of those who they would apply to $(2014 a, 18)$. In this way, 'personhood' can be reflected in 'more comprehensive and suitable fashion' (Honneth 2014a, 8), albeit as dependent on social struggles supportive of such practices in the cosmopolitan sphere.

To go back to an earlier theme, it is this relational content of a cosmopolitanism based on recognition that can overcome the tendencies in liberal and proceduralist models of cosmopolitanism that merely insist on rights without establishing prior their social basis that could make them actual. A key example of the cosmopolitan social relations helping to bridge the abstract right of personhood to a lived social freedom was the Anti-Apartheid struggles in South Africa (SA). Here, the developing norms of cosmopolitan recognition already established in the universal right of personhood was a fundamental contribution for transnational activists in securing the moral/ legal agency of peoples suffering denigration and domination. Indeed, without this moral vocabulary already possessing sufficient institutionalization in the cosmopolitan sphere would have meant an international community deafened to the cries for recognition of universal personhood. Viewed from a cosmopolitical point of view, this struggle was not only for fundamental freedoms within SA but a struggle for the conception of universal HR to live up to its immanent standard of freedom. This register developed through struggles between the 1960s to the 1990s with the vast majority of international organizations, overtime, coming to impose a range of sanctions (economic, military, and social) against the apartheid regime insisting on the full recognition of personhood regardless of race. The importance of norms in this historical development - how an 'ought' became and 'is' (Klotz 1995, 452) - and the overriding of material/strategic interest of states reveals the key development of cosmopolitan sphere of rights: the articulation of a universal standard that went beyond conventional understandings of rights that were assumed to be determined by purely endogenous normative codes within states. Here, the cosmopolitan sphere was a site that not only lent solidarity to local actors struggling against 
apartheid but also provided a 'normative surplus' and refined conception of 830 the idea of universal personhood that could be utilized by those struggling in 831 SA, and elsewhere. It is little coincidence that some Palestinian activists are 832 using the same language to express their personhood within Israel and the 833 occupied territories (Bishara 2002). ${ }^{7}$ There had, of course, been unanimous, 834 global recognition of rational equality throughout the international 835 community since decolonization, however, incomplete and partial. Yet, it 836 was only the normative pressure of this fundamentally refined conception of 837 personhood exerted at the cosmopolitan level that can explain the shifts 838 that occurred in response to the domestic and transnational forms of 839 struggles against apartheid and which may, therefore, be replicated in similar 840 struggles.

Building on the established practices of a universal conception of civil rights, transnational and local activists pushed these to their logical conclusion for the legal equality of all citizens in SA. Taken singularly these actors appear as a combination of transnational civil society organizations: Pan-African solidarities across states (i.e. TransAfrica) (see Edmondson 1986, 164-211); international coordination of working class solidarity (particularly maritime workers) (Berlau 1995); academic, sport, and divestment boycotts. These were met with state-based forms of support such as the Soviet training of MK fighters in the ANC and, later, economic sanctions, such as the Comprehensive Anti-Apartheid Act (in the United States) (1986). These mirrored domestic struggles such as the consumer boycotts, student and labour strikes, and formation of street councils within SA. Yet taken together, these transnational actors were deploying a uniquely cosmopolitan conception of rights that added to both domestic and international conceptions of racial equality in legal personhood. For it not only sought to overturn apartheid structures, thereby rendering a more inclusive national community in SA, but alter what was considered to constitute moral personhood.

In terms of Honneth's criteria to determine mutual recognition - that such practices exist and confer a special type of normative status to individuals from which a specific form of individual relation-to-self must be expected (2014a, $105)$ - the cosmopolitan sphere brought to the Anti-Apartheid struggles a unique claim of recognition. For SA citizenship already presupposed legal 864 personhood, what was lacking was its actualization across races. In this shift, 865

\footnotetext{
${ }^{7}$ Unlike the successful example of anti-apartheid struggles in SA, the Palestinian case of struggle for respect is suggestive of continued non-recognition in the cosmopolitan sphere. That is, despite the UN General Assembly's repeated affirmation of Palestinian rights in the global public sphere, there remains a lack of concerted transnational practice to ensure the actualization of such rights.
} 
fundamental moral and political conditions of what Fanon described as the non-white being's 'zone of nonbeing' $(2008$, xii) - the complete absence of social recognition - was, at least formally, overcome. In turn, this provided a refined framework for ongoing anti-racist struggles generated by ongoing legacies of apartheid and colonialism such as access to land, education, and other forms of formal socio-economic exclusions. The releasing of such conceptions of personhood in SA was not only an example of the exercise of moral freedom but, in turn, contributed to the transformation of society by permitting the public and cosmopolitan questioning of the dominant interpretation of the norms that were deemed to already constitute society. Expressed alternatively, the process allowed persons to go 'beyond given systems of norms in a justified fashion ... and propose new systems of norms' (Honneth 2014a, 104, 112). Of course, the political outcome left many economic and cultural inequalities in place, as consistent with the limited power of rights and the realm of civil society. It is therefore imperative to engage with the uneven development of rights in international society and the declining support for social, economic, and cultural rights that has come about with the dominance of capitalist social relations in global civil society, that stifles these other essential rights that would ensure the actualization of personhood beyond mere civic formalism. Nevertheless, civil rights may be seen as a spur for further gains in social freedom by allowing persons the space to take advantage of formal concessions and the legal surety of opportunity for participation in the process of public will-formation (see Honneth 1995, 117). In other words, the emphasis of struggle must be on the changes in behaviour that can come about through the successful winning of rights (Honneth 2014a, 32).

\section{Solidarity, self-esteem, and public social freedom}

Solidarity can be seen as the public demonstration of the esteem of the value and contribution that the 'otherness' of distinct individuals and groups contributes to a community. ${ }^{8}$ Such recognition is contingent upon a shared perception of those goals that have developed historically for the recognition of specific qualities within a given society (Honneth 1995, 126-30). Despite this seeming deference to common values, solidarity celebrates the radical particularity of each societal member so that struggles for extending the content of esteem and/or the social evaluative framework for esteem, centre on recognizing forms of identity previously ostracized or denigrated

\footnotetext{
${ }^{8}$ It is important to note that in Honneth's discussion of state-based forms of recognition, he restricts his discussion to respect and esteem regarding the collective identities of other countries (see Honneth 2012b, 33-35, 1995, 121-22).
} 
(see Honneth 1995, 96-109). What is considered of social value is 902 contingent on a range of historical and cultural factors and is a fluid 903 condition, in which the ideal conditions for the expression of self-esteem are 904 forms of solidarity that are open, pluralistic, and participatory, through 905 which a broad array of qualities can be recognized as valuable. Such 906 diversity not only widens the freedom and quality of community but 907 broadens the potential expression of freedom for each individual. At the 908 same time it implies that cosmopolitanism should no longer be wedded to 909 statism or methodological nationalism that would restrict the public form 910 of social freedom under an exclusionary political model. The key, to repeat 911 once again, is to move to a social-relational grounding of cosmopolitanism. 912

To be adequately reciprocal, solidarity must inspire not just 'passive 913 tolerance' but a 'felt concern' for what is particular about an individual, 914 group, or peoples. It is only to the degree that each actively cares 915 (by providing space and conditions) for the development of the other's 916 characteristic/s that this shared goal between subjects can be realized 917 (Honneth 1995, 129). 'Felt concern' should not be mistaken as compassion, 918 the resources of which are limited in world politics, as the literature on the 919 'active care for strangers' demonstrates. Rather, what recognition theory 920 gestures towards is the reciprocal understanding between interaction 921 partners of the necessity for mutual esteem of the attributes or contribution of 922 an individuals/groups for self-actualization. Honneth's analysis of solidarity, 923 given that it is focused only on local communities within the state, provides 924 only part of the picture. For relations in the cosmopolitan sphere, consistent 925 with increases in interactions through 'globalization', require the necessary 926 recognition of esteem for those different ways of life that contribute to 927 international society and the diverse articulation of individual freedoms 928 within it. Honneth (1995, 166ff) has argued that struggles for recognition 929 emerge not just in defence of traditional forms of life but in challenging 930 existing ways of life that have become intolerable. This argument implicates 931 not only local forms of esteem that hinder the expression of wider solidarities 932 beyond it but also those social spheres of interaction that have become a 933 fetter on self-actualization in world politics. However, as cosmopolitan 934 society is only weakly developed and holds highly contested understandings 935 of esteem, this suggests ongoing conflicts regarding both the evaluative 936 framework and the content/qualities that are to be esteemed in the global 937 sphere. Acts of denigration and disrespect cut across states, cultures, and 938 classes, and yet whether the potential for transformative collective action at 939 the cosmopolitan level to expand existing patterns of recognition will be 940 violent, or discursive, or whether they will happen at all, is indeterminate. 941 Struggles of the so-called Fourth World for greater cultural esteem are 942 indicative of such claims for distinct ways of life. Far more violent examples 
can be seen in the complete ruptures of basic recognition where the 'other' is regarded as inanimate or inferior, creating conditions for denigration and aggression found in ethnic wars (Lindemann 2014, 483). Arguably, what animates these two otherwise disparate examples is the deficiency in the evaluative framework of esteem in the cosmopolitan sphere. This is where the importance of the global public sphere becomes acute for it allows for the possible emergence of the ideal communicative form of interaction (i.e. democratic negotiations) as 'the proper means' for the realization of such solidarity within community (Honneth 2014a, 564, 565). Of course, we are far from this ideal and yet aspects of it are not only already present but in the process of struggles for their extension and expansion.

In the public sphere, in order to satisfy individual/group need for esteem and the articulation of this social freedom throughout community, solidarity is dependent on at least three things: rationally guided actions (i.e. actions that seek to guarantee individual freedom), a shared evaluative framework, and sufficient institutionalization of such actions. The formal aspect of 'public life' such as deliberation and communication in the co-creation of laws, policy, and regulations, are not the self-referential pursuit of egocentric subjects but a dialogue between citizens within the plurality of ethical life - the rational articulation of needs are deliberated rather than one-sidedly insisted on or subjectively pursued (as in the case of rights). This is an idea that Honneth has developed from Habermas' account of the ongoing deliberative processes of social inclusion within the (statist) public sphere. However, Honneth extends this conception to include counter-publics positing that there are many 'public spheres', most of which exist alongside each other without coming into contact (2014a, 258). Voting, assembly, association, and parliamentary legislation, are some of the communicative conditions that institutionalize the public examination of opinions between interaction partners in a discursive exchange about what policies are to govern their community (Honneth 2014a, 260). One could add here the nascent forms of global governance as possessing tendencies towards the same communicative conditions, however, weakly developed they are. Through the historical development of democratic processes - and a host of related norms that enable such participation in shared deliberation - Honneth describes how a 'reciprocal recognition emerged' in which members became 'capable of recognizing each other as equally entitled citizens' with a democratic will equal to all others (2014a, 261, 266, 267). These processes enable members to 'take up the perspective' of the 'We' whilst judging the consequences of their own actions and attempting to improve their own living conditions in communication with others (Honneth 2014a, 274). However, Honneth admits that this historical process was politically subsumed under nationalism that placed the loyalty of members over any 'international convictions' that could have widened the 
ambit of such processes of 'unforced will formation'. That is, the capacity for 986 taking up the perspectives of the cosmopolitan 'we' was artificially closed-off 987 by social misdevelopments in, and of, the state. This implies the cosmopolitan 988 public sphere as an intrinsic, even natural, development of public-will 989 formation, despite it being colonized or overridden by the state. Arguably, the 990 forms of regional democratic processes in the EU provide some evidence for 991 the reemergence or freeing of this inclination to cosmopolitanism. 992

Honneth provides a useful test for the existence of a public sphere today: 993 '[o]nly if such a communicative understanding about the consequences of 994 their associated action in the group comes about can we speak of the "We" of 995 the public' (2014a, 273). The question is then whether we can identify a 996 cosmopolitan public sphere in these terms? As far back as the 18th century, 997 Kant $(1979,153 \mathrm{ff})$ was already observing the emergence of a cosmopolitan 998 public sphere within Europe's appreciation of the French Revolution in which 999 a 'judging public' was considered evidence of the causality of a 'cosmopolitan 1000 freedom'. This was taken as proof of a cosmopolitan public sphere in which 'a 1001 violation of rights in one part of the world' was now 'felt everywhere' (Kant 1002 2005, 107, 108). Forward two centuries, we find 47.8\% of respondents 1003 identifying as world citizens in the World Values Survey (WVS), and a further 1004 $30 \%$ of respondents strongly identifying as such (Bayram 2014, 452). For 1005 Honneth, along Kantian lines, contemporary evidence of the cosmopolitan 1006 public sphere can be found in the 'feelings of either enthusiastic approval 1007 in the case of struggles for emancipation, or with disgust in the case of 1008 oppression' (2014a, 335). History has, of course, displayed both civilizing and 1009 de-civilizing processes at work. The dispute over immigration policies across 1010 the globe attest that many people do not see themselves primarily as members 1011 of humanity, despite whatever the WVS may indicate. Yet, despite the 1012 unevenness and reversals of such developments (Linklater 2011, esp. Ch. 4), 1013 these demonstrate an institutionalization in the cosmopolitan public sphere of 1014 the regard for the 'consequences' of humankind's associated action/s within 1015 the whole. Here, debates on the rights and responsibilities of climate change, 1016 especially to those of future generations, provides a most telling example. As 1017 stated previously, Honneth's model is based on the existence of many public 1018 spheres that allows us to see the formal international political institutions as 1019 displaying an emergent form of communicative understanding. Honneth has 1020 looked to the UN as a democratic public sphere in which HR has 1021 subordinated constitutional rights to international laws (i.e. Russell Tribunal) 1022 and the EU as an example of transnational public sphere (despite this 1023 communicative potential being overshadowed by concerns for unhindered 1024 economic transactions) (2014a, 279, 80, 328). Perhaps more importantly, are 1025 what Honneth refers to as 'de-hierarchical publics on a global scale' including 1026 the 'transnational communicative communities' such as NGOs (i.e. Amnesty, 1027 
Doctors Without Borders, Greenpeace) and, more speculatively, the internet 1028 as a site of a borderless public (Honneth 2014a, 300, 301). Along these lines, 1029 we can identify other cosmopolitan deliberative public spheres such as 1030 the World Social Forum (though this rejects any binding decision-making capacity) and La Via Campessina that was explicitly created as a transnational communicative institution based on improving the living conditions of its global members coordinated through a decentralized international committee. As institutions that include all those to be effected by their decisions, both bodies demonstrate an institutionalization of a democratic, cosmopolitan public sphere that possess unique recognition processes from which to judge the consequences of their actions (Honneth 2014a, 288).

Whether this possibility will lead to the further transnationalization of democracy is dependent on the willingness of those who identify as 'cosmopolitan citizens' to continue to reconcretize such communities of interaction, just as it does on those who would resist it. The massive increases in transnational activism are anticipative of such possibilities in which solidarity makes participants feel responsible for each other. Yet, this requires a 'political culture that nourishes and permanently enriches such feelings of solidarity' - and a capacity to resist those challenges from localized obligations of custom and tradition (Honneth 2014a, 290-92). Lacking the nationalism and close ethical ties of the state, the cosmopolitan sphere requires alternative motivational resources to sustain such a movement. For Honneth the 'search' is on for 'more abstract forms of solidarity' (2014a, 330 ). With the dramatic lurch to the far right globally, this possibility seems more distant than ever. The key challenge is for world citizens to develop an understanding that the cosmopolitan sphere deserves support because it represents part of the essential conditions for their own freedom. That is, a conscious awareness that cosmopolitan social relations can provide an effective form of solidarity against the vast transnational forces (economic, environmental, and social) that mere local/national attachments can do little to mediate effectively. Just as domestic forms of democratic ethical life, deliberation, and will-formation, must be held by their participants as 'institutions of unforced reciprocity in the satisfaction of needs, interests, and aims' (Honneth 2014a, 254), so too must social freedom in the cosmopolitan sphere be deemed as a relation of 'mutual dependence' between all individuals and this ethical sphere (Honneth 2014a, 328, 320).

\section{Conclusion}

This article has insisted on pursuing a relational account of cosmopolitanism. Specifically, it has posited that cosmopolitan forms of recognition are evident in the forms of personal relations that proliferate over state borders, the 
transnational nature of the HR regime, and in forms of global public 1068 life whether of state institutions, non-state actors including global social 1069 movements, an even information sharing networks. Expressed alternatively, 1070 cosmopolitanism already constitutes a realistic expectation of social freedom 1071 in the relations between individuals when we consider human rights, or 1072 solidarity across state borders, or in debates over issues of global affect 1073 (climate, refugees, trade, and so on). Some of these practices have already 1074 been established in institutions, others indicate a widening of interaction 1075 partners and the possible expansion of social freedom in this unique sphere. 1076 From being recognized as bearer of needs, as a bearer of responsibility (and 1077 agency), and as a bearer of something of social value, cosmopolitanism 1078 provides the social freedom that comes from one's recognition as a human in 1079 the world (i.e. being recognized as a universal agent of co-freedom). We could 1080 express this as self-confidence (personal need), self-respect (private, rights), 1081 and self-esteem (public, solidarity), to self-being in the cosmopolitan sphere. 1082

Yet, the examples discussed in the vignettes suffer from many obstacles to 1083 their full realization. Given current socio-political conditions, claims for 1084 cosmopolitan recognition must be directed within nation-states and be 1085 supported by them. Equally so, cosmopolitan relations are ensnared within 1086 capitalist relations of production that permeate throughout transnational 1087 civil society. Without fundamental institutional development, cosmopoli- 1088 tan processes of recognition remain cornered by the state and capital, if not 1089 reducible to either. It is only future struggles that will indicate how this 1090 institutional framework may be transformed - a question of human 1091 agency - and in the absence of which we should not overestimate the future 1092 of cosmopolitan civic and public attitudes. Nevertheless, despite their 1093 weaknesses, these examples do prove the existence of distinct forms of 1094 recognition, their necessity for stable identity formation in an increasingly 1095 'globalized' world, and possible future sites of struggle towards reciprocity 1096 or mutuality in world politics.

Their limits, however, lead to the question of the ideal form for the 1098 political and legal institutionalization of cosmopolitan recognition - and 1099 inevitably to a discussion of the possibility of a 'world state'. Given the 1100 fetishization of the state in the discipline of IR, this is understandable. But 1101 nothing of the above should be taken as arguing for the suitability or 1102 inevitability of the world state as essential to recognition, as advocated by 1103 some. For example, Wendt has used a conception of Hegelian recognition 1104 (albeit unrelated to Honneth's) to advocate for the inevitability of a 1105 Weberian World State. For him, the rational response to the violent pursuit 1106 of recognition in IR will lead to a world state in which recognition no longer 1107 rests on a 'territorial' but 'global' basis (Wendt 2003, 494, 517). Dufeck has 1108 advocated more recently for a 'global state-like entity with coercive powers' 1109 
over the 'kind of non-hierarchical, dispersed and/or decentralized institutional arrangements' $(2013,177)$ that my argument gestures towards. Both Wendt and Dufeck place problematic limitations around the politics of recognition, however: the former limits recognition to the creation of the conditions of basic security through law (Wendt 2003, 515), the latter, looks to moral imposition through institutional design, rather than the self-actualized freedom of all members. In distinction, whilst we have inherited the state, it is not inevitable, nor would I suggest the most suitable institutional form for mutual recognition across all humanity. Rather, the implications of recognition theory outlined here is that cosmopolitan duties are based on mutual obligations owed between interaction partners, based on reciprocity as understood by the gains for self-actualization for all that such a social freedom promises. As I posited in the opening, recognition processes can be practiced and institutionalized in any myriad of ways. Indeed, the key advantage that stems from this alternate, relational grounding of cosmopolitanism is its non-exclusivity, as opposed to the enforcement through a fixed hierarchical institution. This does not mean passivity to non-recognitive social practices, however. Intolerant or anti-egalitarian practices that reject openness, plurality, and participation - that denigrate love, rights, solidarity, and being - should be struggled against and dismantled for they restrict the recognition of some, and therefore the social freedom of all.

This is premised on the argument that without a cosmopolitan dimension of recognition individuals/groups may secure locally their 'love, rights and solidarity' but nevertheless remain misrecognized or unrecognized in the world around them and thus lack vital conditions necessary for their identity, individuality, and freedom in the conditions of late (globalized) modernity. To the degree that individuals have an external personality that must be reflected beyond local forms of ethical life, there must be an additional sphere of identity beyond the state fundamental to the full expression of individual autonomy in the world. The real question regards the requisite level - or the comprehensiveness - of their institutionalization for stable and habitual attitudes of recognition between self and other in this cosmopolitan sphere. How cosmopolitan recognition constitutes a unique sphere of social freedom can only be examined through further research. Rather than seeking to build cosmopolitan institutions and impose them from outside, recognition theory and normative reconstruction offer a way to understand these relations and processes as already existent, however, partial and incomplete their institutionalization. By locating them in existing social relations means that the idealism of cosmopolitanism is no longer a point of critique. Moreover, the diversity of such struggles for recognition demonstrates an openness to the 
socio-cultural horizon that overcomes any charge of a monist universalism. 1152 Cosmopolitanism must be relational and free, or it will not be at all.

\section{References}

Anderson, Joel. 1995. 'Translator's Introduction'. Translator's Note', The Struggle for Recog- 1157 nition, viii .

Anderson, Joel, and Axel Honneth. 2005. “Autonomy, Vulnerability, Recognition, and Justice.” 1159 In Autonomy and the Challenges of Liberalism, edited by Christman J., and Anderson J., 1160 127-49. Cambridge: Cambridge University Press.

Baker, Catherine. 2016. 'The 'Gay Olympics'? The Eurovision Song Contest and the politics of 1162 LGBT/European belonging,' European Journal of International Relations (Online First). 1163

Bayram, A. Burcu. 2014. "What Drives Modern Diogenes? Individual Values and Cosmopolitan 1164 Allegiance.” European Journal of International Relations 21(2):451-79.

Berlau, Henrik. 1995. "Maritime Unions Against Apartheid." In Embargo: Apartheid's Oil 1166 Secrets Revealed, edited by $\square$, 296-305. Amsterdam: Amsterdam University Press. 1167

Birdal, Sinan Mermet. 2015. "Between the Universal and the Particular: The Politics of Recog- 1168 nition of LGBT Rights in Turkey.” In Sexualities in World Politics, Chapter 7, edited by 1169 M. L. Picq, and M. Thiel, $\square-\square$. London: Routledge,. 1170

Bishara, Marwan. 2002. Palestine/Israel: Peace or Apartheid. London: Zed Books. 1171

Brennan, Timothy. 1997. At Home in the World: Cosmopolitanism Now. $\mathbf{\square}:$ Harvard University 1172 Press. 1173

Brincat, Shannon. 2012. "On the Methods of Critical Theory: How CIRT has Advanced 1174 the Project of Emancipation in the Early Frankfurt School." International Relations 1175 26(2):218-45. 1176

Brincat, Shannon. ed. 2015. Recognition, Violence and the Problem of Ethical Community. 1177 London: Routledge. 1178

Q14 Palgrave Macmillan.

Q15 Butler, Judith. 2004. "Beside Oneself: On the Limits of Sexual Autonomy.” In Undoing Gender, 1181 edited by J. Butler, 17-39. London: Routledge.

Cox, Robert W. 1995. "Civilizations: Encounters and Transformations.” Studies in Political 1183 Economy 47:7-31.

Croce, Mariano. 2015. "From Gay Liberation to Marriage Equality: A Political Lesson to 1185 be Learnt." European Journal of Political Theory $\mathbf{\square}: 1-20$.

Daase, Christophe, Caroline Fehl, Anna Geis, and Georgios Kolliarakis. eds. 2015. Rethinking a 1187 Political Concept in a Global Context. Hampshire: Palgrave Macmillan. 1188

Deranty, J-P, and E. Reanult. 2007. "Politicizing Honneth's Ethics of Recognition.” Thesis 1189 Eleven $\square: 92-111$.

Dufek, Pavel. 2013. "Why Strong Moral Cosmopolitanism Requires a World-State." 1191 International Theory 5(2):177-212.

Duncombe, Constance. 2015. 'Representation, Recognition and Foreign Policy in the Iran-US 1193 Relationship,' European Journal of International Relations (Online first). 1194

Fanon, Frantz. 2008. Black Skin, White Masks. New York: Grove Press. 
Fraser, Nancy, and Axel Honneth. 2003. Redistribution or Recognition?: A Political-Philosophical Exchange. London: Verso.

Haacke, Jürgen. 2005. "The Frankfurt School and International Relations' on the Centrality of 1198 Recognition." Review of International Studies 31(1):181-94.

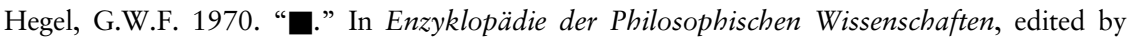

Hegel, G.W.F. 1991. Elements of the Philosophy of Right, (H.B. Nisbett, trans.). Cambridge: Cambridge University Press.

Heins, Volker. 2005. "Realising Honneth: Redistribution, Recognition, and Global Justice." Journal of Global Ethics 4(2):141-53.

Hobson, John. 2007. "Is Critical Theory Always for the White West and for Western Imperialism? Beyond Westphalian Toward a Post-Racist Critical IR." Review of International Studies 33(S1):91-116.

Honneth, Axel. 1991. The Critique of Power: Reflective Stages in a Critical Social Theory, (K. Baynes, trans.). Cambridge, MA: MIT Press.

Honneth, Axel. 1995. The Struggle for Recognition: The Moral Grammar of Social Conflicts. Cambridge, MA: MIT Press.

Honneth, Axel. 1996. The Fragmented World of the Social: Essays in Social and Political

'From Adorno to Habermas: On the Transformation of Critical Social Theory'.

Honneth, Axel. 1997. "Habermas' Anthropology of Knowledge: The Theory of KnowledgeConstitutive Interests." In The Critique of Power, (K. Baynes, Trans.) $\square$. Boston, MA: MIT Press.

Honneth, Axel. 2003. "The Point of Recognition: A Rejoinder to the Rejoinder." In Redistribution or Recognition? A Political-Philosophical Exchange, edited by N. Fraser, and A. Honneth, $\square$. London: Verso.

Honneth, Axel. 2007. "Rejoinder." In Recognition and Power: Axel Honneth and the Tradition of Critical Social Theory, edited by B. van den Brink, and D. Owens, $\square$. Cambridge: Cambridge University Press. In Disrespect: The Normative Foundations of Critical Theory, edited by Cambridge: Polity Press.

Honneth, Axel. 2009. Pathologies of Reason, (J. Ingram, trans.). New York: Columbia University Press.

'A Social Pathology of Reason: On the Intellectual Legacy of Critical Theory'.

Honneth, Axel. 2012b. "Recognition Between States: On the Moral Substrate of International Relations." In The International Politics of Recognition, edited by T. Lindemann, and E. Ringmar, 25-38. Boulder, CO: Paradigm Publishers.

Honneth, Axel. 2014a. Freedom's Right. New York: Columbia University Press.

Honeth, Axel. 2014b. "Rejoinder." Global Discourse 4(4):564-65.

Q22 Honneth, Axel, and Jacques Rancière. 2016. Recognition or Disagreement? A Critical Encounter on the Politics of Freedom, Equality, and Identity. NY: Columbia University Press.

Hutchinson, Emma. 2014. "A Global Politics of Pity? Disaster Imagery and the Emotional Construction of Solidarity After the 2004 Asian Tsunami." International Political Sociology 8(1):1-19. 
Kant, Immanuel. 2005. "Perpetual Peace.” In Kant: Political Writings, edited by H. S. Reiss, Cambridge: CUP.

Klotz, Audie. 1995. "Norms Reconstituting Interests: Global Racial Equality and U.S. Sanctions 1247 Against South Africa." International Organization 49(3):451-78.

Lindemann, Thomas. 2014. "Interest, Passion, (Non)Recognition, and Wars: A Conceptual Essay.” 1249 Global Discourse 4(4):483-96.

Lindemann, Thomas, and Eric Ringmar. eds. 2012. The International Politics of Recognition. 1251 Boulder, CO: Paradigm Publishers.

Linklater, Andrew. 2011. The Problem of Harm in World Politics. Cambridge: CUP. 1253

Markell, Patchen. 2003. Bound by Recognition. Princeton, NJ: Princeton University Press. 1254

Marshall, T.H. 1950. Citizenship and Social Class and Other Essays. Cambridge: Cambridge 1255 University Press.

Ringmar, Erik. 2012. "Introduction the International Politics of Recognition." In The Interna- 1257 tional Politics of Recognition, edited by T. Lindemann, and E. Ringmar, 3-24. Boulder, 1258 CO: Paradigm Publishers.

Sorial, S. 2008. "Law, Cosmopolitan Law, and the Protection of Human Rights." Journal of 1260 International Political Theory 4(2):241-65.

Stychin, Carl F. 2003-2004. "Sam-Sex Sexualities and the Globalization of Human Rights 1262 Discourse." 49 McGill L.K 951:

Taylor, Charles. 1992. "The Politics of Recognition." In Multiculturalism and the Politics of 1264 Recognition, edited by A. Gutmann, $\square$. Princeton, NJ: Princeton University Press.

Thörn, Håkan. 2006. Anti-Apartheid and the Emergence of a Global Civil Society. London: 1266 Palgrave Macmillan.

Wendt, Alexander. 1987. "The Agent-Structure Problem in International Relations Theory.” 1268 International Organization 41(3):.

Wendt, Alexander. 1992. "Anarchy is What States Make of It." International Organization 1270 46(2):391-425.

Wendt, Alexander. 1999. Social Theory of International Politics. Cambridge: Cambridge 1272 University Press.

Wendt, Alexander. 2003. "Why a World State is Inevitable." European Journal of International 1274 Relations 9(4):491-542.

Wilson, Ara. 2002. "The Transnational Geography of Sexual Rights.” In Truth Claims: 1276 Representation and Human Rights, edited by M.P. Bradley, and P. Petro, 253-65. 1277 New Brunswick, NJ: Rutgers University Press. 1278 